\title{
Allelopathic Effect of Jatropha (Jatropha curcas) on Chilli (Capsicum annum) and Green Gram (Vigna radiata)
}

\author{
Ujjal Baruah $^{1 *}$, Kaushik Das ${ }^{1}$, Utpal Kotoky ${ }^{2}$ and Sonbeer Chack ${ }^{1}$ \\ ${ }^{1}$ Department of Crop Physiology, Assam Agricultural University, Jorhat-785013, \\ Assam, India \\ ${ }^{2}$ Department of Horticulture, Assam Agricultural University, Jorhat-785013, Assam, India \\ *Corresponding author
}

\section{A B S T R A C T}

Experiments were carried out to determine the possible allelopathic effects of jatropha (Jatropha curcas) on chilli (Capsicum annum) and green gram (Vigna radiata). Aqueous extract of jatropha leaf at $5 \%, 10 \%, 15 \%$ and $20 \%(\mathrm{~W} / \mathrm{V})$ concentrations were bio-assayed

Keywords

Jatropha (Jatropha

curcas), Chilli

(Capsicum annum),

Vigna radiata

Article Info

Accepted:

06 May 2018

Available Online:

10 June 2018 against germination and seedling growth of chilli and green gram. In both crops, germination percentage, germination index, plumule and radicle length, fresh and dry weight of plumule and radicle were appreciably reduced by aqueous extract of jatropha leaf in a concentration dependent manner. However, germination of green gram seed was found to be more sensitive to jatropha leaf extract. In one pot culture experiments aqueous extract of jatropha leaf at $5 \%, 10 \%, 15 \%$ and $20 \%(\mathrm{~W} / \mathrm{V})$ concentrations were applied into soil to determine the allelopathic activity of jatropha on growth and development of chilli and green gram. Plant growth of green gram in terms of plant height, leaf number, leaf area, root volume, shoot and root dry weights were reduced significantly by aqueous extract, particularly at higher concentrations. Relative leaf water content, total chlorophyll content and leaf N P K content of green gram were also reduced by the aqueous extract. Similar type of inhibitory effect of jatropha was recorded in chilli at early vegetative growth stage. However, no significant growth and yield reduction were recorded in chilli with extract of jatropha leaf at maturity. From this investigation, it can be suggested that chilli may be grown as an intercrop with jatropha.

\section{Introduction}

The exploitation of bio-energy sources of fuel has recently been given much prominence by the scientific community and commercial entrepreneurs as a way to solve the energy crisis (Abugre et al., 2015). In this regard the production and use of bio-diesel are becoming an important concern across different countries of the world including India
(Goswami et al., 2011). A limited stock of fossil fuels, problems of global warming, generation of employment and income opportunities are a few driving forces for increased use of bio-diesel (Mathys, 2008). As India meets her major energy requirement through the consumption of diesel, the demand for diesel will increase further in the coming years and, by 2025, almost 90 per cent of India's fuel requirement will be fulfilled 
only through import (CSIS, 2006). The blending of biodiesel with diesel can reduce the quantum of such import. Several vegetable oils available commercially have been tested as fuel components for diesel engines. Some of these oils are soybean, cottonseed, sunflower, rapeseed, safflower, peanut, algal oil etc. (Spolaore et al., 2006). However, growing food crops only for biofuels in monoculture pattern is often criticized because of the direct competition of land for food production. The price increases on world food markets are partly a result of this competition (Müller, 2008). In this respect, among various plants, Jatropha curcas (jatropha) has been found to be a highly promising biofuel species since it does not compete for human consumption. It is of short gestation period, hardy nature with high quality oil content. The jatropha oil is close to cottonseed and better than rapeseed, groundnut and sunflower, which gives no pollution, when it is burnt (Abugre and Sam, 2010).It has gained popularity as biodiesel plant in both developed as well as developing countries of the world. Its seeds contain predominantly crude oil, protein and fibers (Brittaine and Lutaladio, 2010). Oil extracted from jatropha seeds is non-edible and is mainly used as biodiesel energy (Ullah et al., 2014).

As a bio-fuel crop, jatropha is grown in widely spaced row at $3 \mathrm{~m}$ apart and after pruning, the newly emerged canopy does not cover the land adequately and hence frequent weeding is required (Singh et al., 2007). This wide inter row spacing can be effectively used to grow some intercrops, which will not only reduce weed infestation but also increase the return from the land. Therefore, it is suggested that growing of some intercrops with jatropha plantation will help in mitigating both food and energy crises (Abugre and Sam, 2010).

However, it is documented that various intercropping system failed to produce the expected superior results. The failure of most crops in an intercropping system has been attributed to allelopathic effect of the tree species. In agro-ecosystem, it plays a significant role in 'crop-weed', 'crop-crop' and 'crop-weed-microbe' interactions, and thereby effects growth and development of receiver plants. Thus, the research on allelopathic interactions of biofuel trees with intercropped food crops emerges as a major scientific and policy issue.

\section{Materials and Methods}

Aqueous extract of jatropha leaf was prepared following the method given by Maharjan et al., (2007). Fresh jatropha leaves weighing 200 gm were ground homogeneously in a mortar and mixed with $1000 \mathrm{ml}$ of distilled water and kept for 24 hours. Then the slurries were strained through two layers muslin cloth and were centrifuged at $4500 \mathrm{rpm}$ for 10 minutes. The supernatant was considered as $20 \%$ aqueous extract. By subsequent dilution with distilled water, aqueous extracts of $15 \%$, $10 \%$ and $5 \%$ were prepared and kept at $4{ }^{\circ} \mathrm{C}$ till further use.

\section{Aqueous extract bioassay}

Bioassay of jatropha was carried out following the procedure of Rejila and Vijayakumar (2011). Surface of the French bean and brinjal seeds were sterilized by dipping in 0.10 percent (W/V) $\mathrm{HgCl}_{2}$ for one minute and rinsed several times with distilled water. Ten seeds of French bean and brinjal were placed in separate glass Petri dishes (15 cm diameter) with 3 replications fitted with single layer of filter paper. The filter papers of different Petri dishes were moistened sufficiently by adding equal volume $(15 \mathrm{ml})$ of aqueous extract of different concentrations. A control was set with distilled water. The Petri dishes were covered and kept in room temperature. The covered Petri dishes were opened periodically 
for aeration and to add stock solutions to keep the filter paper moistened.

\section{Preparation of pot mixture}

The collected soil was sun-dried, ground and screened to pass through a $2.5 \mathrm{~mm}$ sieve. The recommended doses of inorganic and organic fertilizer for chilli (100:50:50 kg of NPK ha and 20 tonne of $\mathrm{FYMha}^{-1}$ ) and for green gram (15:35:0 kg of NPK ha- ${ }^{-1}$ and 1.3tonne of FYMha $^{-1}$ ) were added to each pot containing 5 $\mathrm{kg}$ of soil.

\section{Sowing of seeds}

Chilli seeds (variety Suryamukhi) and Green gram seeds (variety Pratap) were surface sterilized by dipping in $\mathrm{HgCl}_{2}(0.10 \%)$ for 1 minute and ringed several times with distilled water and sown (10 seeds in each pot) at a depth of $2 \mathrm{~cm}$ of soil. However, after germination, three seedlings per pot were kept for recording different parameters. Throughout the entire experimental period, optimum level of moisture was maintained by adding water as and when required.

\section{Details of treatment}

Various concentrations of aqueous extracts of jatropha were applied in different pots (soil application, $500 \mathrm{ml} \mathrm{pot}^{-1}$ ) at 14 days after sowing (DAS), 21 DAS and 28 DAS following the procedure of Rejila and Vijayakumar (2011). The experiment was carried out with four replications with the following treatments:

$\mathrm{T}_{1:} 5.0 \%$ aqueous extract

$\mathrm{T}_{2}: 10 \%$ aqueous extract

$\mathrm{T}_{3}: 15 \%$ aqueous extract

$\mathrm{T}_{4}: 20 \%$ aqueous extract

One set was kept as control without application of aqueous extract.

\section{Results and Discussion}

Experiment No. 1 and Experiment No. 2 (aqueous extract bioassay) were conducted under laboratory condition to determine the allelopathic potential of different concentrations of aqueous extract of jatropha leaf on germination behaviour of chilli and green gram. It was observed that germination percentage of both chilli and green gram were reduced by jatropha leaf extract. In both the crops, highest and lowest reduction in germination percentage were observed with 5 and 20 per cent concentrations of aqueous extract respectively, which revealed that inhibition of germination of chilli and green gram by jatropha leaf extract was concentration dependent. This finding of the present investigation is in line with the results of other studies reported by several workers. For example, Abugre and Sam (2010) recorded similar reduction in seed germination of several crops by aqueous extract of jatropha leaf.

Data tabulated in table 1 and 2 shows that allelopathic action of jatropha has caused some inhibitory effect on both the crops with minimum and maximum inhibition in 5\% and $20 \%$ concentration respectively, which indicated that effect on both the crops chilli and green gram were concentration dependent. This finding of the present investigation is in line with the results of other studies reported by several workers. For example, Abugre and Sam (2010) recorded similar reduction in seed germination of several crops by aqueous extract of jatropha leaf.

Germination index is a criterion to evaluate the speed or rate of germination. It was found that the speed of germination was retarded by aqueous extract of jatropha leaf as indicated by low germination index values. Plumule and radicle length of both the test crops were reduced to a highest extent by 20 per cent 
aqueous extract of jatropha leaf. Similar trend was recorded in case of fresh and dry weights of seedlings. Similarly it was observed that both plumule and radicle fresh and dry weights of chilli and green gram were reduced by aqueous extract of jatropha leaf. In both the crops, highest and lowest reduction in fresh and dry weights were observed with 5 and 20 per cent concentrations of aqueous extracts respectively, which revealed that reduction in fresh and dry weights by jatropha leaf extract was concentration dependent. This finding is in line with the results reported by Abugre and Sam (2010). They recorded similar reduction in seedling weights of several crops by aqueous extract of jatropha leaf.

Result of the present investigation revealed thatwater soluble phytotoxic substances were present in jatropha leaf, which inhibit germination and early seedling growth under laboratory condition in a concentration dependent manner. Swaminathan et al., (1989) reported that the potential compounds released from donor plants, which could induce inhibitory effect on germination of receiver plants, were primarily phenolic acids. The release of phenolic compounds adversely affects the germination and growth of receiver plants through their interference in energy metabolism, cell division, mineral uptake and biosynthetic processes (Rice, 1984). Several researchers reported similar allelopathic effects of jatropha on other crops also. For example, Hassan et al., (2013), reported that aqueous leaf extract of jatropha could inhibit seed germination, shoot and root growth in millet. Abugre and Sam (2010) reported negative allelopathic effects of jatropha leaf extract on several receiver plants.

From the recorded data of the present investigation, it was observed that reduction in germination percentage in chilli with 20 per cent concentration of aqueous extract was 39.39 per cent over control, whereas in green gram, it was 51.28 per cent (Fig. 1). All the applied concentrations of aqueous extract of jatropha leaf exhibited pronounced inhibitory effects on germination percentage, plumule and radicle length, fresh and dry weights of plumule and radicle of green gram compared to chilli. Therefore, it is noteworthy to mention that germination and seedling growth in chilli, compared to that of green gram, appeared to be less sensitive to aqueous extract of jatropha leaf. Radicle growthis found to be more sensitive to aqueous extract than plumule in both the tested crop. Such type of variation in performance and sensitivity among different plant species to allelochemicals, as observed in our study, has also been documented by other researchers (Callaway et al., 2005; Jensen and Ehlers, 2010). Saadaoui et al., (2015), documented differential rate of inhibition on germination rate and root growth of different species by aqueous extract of Ricinus communis L.

A perusal of the data gives the indications that leaf nitrogen, phosphorus and potassium contents of chilli and green gram were affected by aqueous extract of jatropha leaf (Table 3 and 4). The inhibitory effect on leaf nitrogen and phosphorus content of chilli was recorded at initial stage 50 DAS (vegetative stage), but such inhibitory effect was not observed in the later stages110 DAS (reproductive stage) of growth of chilli. However, in case of green gram, at 30 DAS (vegetative stage) and 50 DAS (reproductive stage), except 5per cent, all other applied concentrations of aqueous extract significantly reduced leaf nitrogen content. Similarly, leaf phosphorus content of green gram was significantly reduced by all the applied concentrations of aqueous extract both at 30 DAS and 50 DAS. Although in chilli, at 50 DAS (vegetative stage), all the applied concentrations of aqueous extract significantly reduced leaf potassium content, such inhibitory effect was not recorded in the latter 
stages of growth. In case of green gram, at 30 DAS and 50 DAS, all applied concentration significantly reduced leaf potassium content.

From the recorded data it is evident that at all the recorded phases of plant growth, shoot and root dry weights of green gram were significantly reduced by jatropha leaf extract in a concentration dependent manner (Fig. 2 and 3). In contrast, root and shoot dry weights of chilli were reduced only at higher concentrations (Fig. 4 and 5). Moreover, this inhibitory effect was recorded only at early growth stage (50 DAS) of chilli. Khan et al., (2008), observed similar results; they recorded significant reductions in shoot and root fresh and dry weights of receiver plant by aqueous extract of donor species.

Reduction of nutrient content in the leaf blade can be explained in the light of several research findings. Several weed and crop residues were found to inhibit uptake of nitrogen, phosphorus and potassium in corn (Bhowmic and Doll, 1982) and in soybean (Bhowmic and Doll, 1984). Chambers and Holm (1965) reported that common bean plant absorbed less phosphorus when grown in association with other bean plant than when grown alone and they suggested that allelopathy was responsible for such effect. Norby and kozlowski (1980) observed that phosphorus concentration in red pine was reduced when red pine trees were watered with aqueous extract of Lonicerataturica or Salidagogugntia foliage. Abenavoli et al., (2010) reported that in maize seedlings, nitrate uptake was affected by trans-cinnamic, ferulic and $p$-coumaric acids in a concentrationdependent manner and trans-cinnamic acid appeared to be the strongest inhibitor.

It appeared that different allelochemicals might have been released from donor residues either by leaching or decomposing which were involved in the process of mineral uptake of the receiver plant. Harper and Balke (1981) reported that $\mathrm{K}^{+}$absorption was reduced by salicylic acid $\left(5 \times 10^{-4} \mathrm{M}\right)$ in oat, wheat, barley and maize. They also observed reduced uptake of $\mathrm{K}^{+}$by excised oat root in the presence of salicylic and ferulic acids in a concentration dependent manner. Reversible inhibition of uptake of phosphate by vanillic acid (Glass, 1973) and potassium by $p$-hydroxy-benzoic acid (Glass, 1974) in excised barley root were also reported.

Several research workers have explained the probable mechanisms of inhibition of mineral uptake by allelochemicals. Phenolic allelochemicals can also inhibit plants from absorbing nutrients from surroundings and affect the normal growth of plants (Li et al., 2010). Salicylic acid depolarised the electrical potential in epidermal cells of barley root (Glass and Dunlop, 1974) and in oat root (Balke, 1985). It was also observed that allelochemicals inhibited plasma membrane ATPase isolated from oat roots. Various allelochemicals had been found to inhibit $\mathrm{O}_{2}$ consumption by mitochondria (Koeppe and Miller, 1974) and thus allelochemicals can decrease ATP production by altering mitochondrial activities. Allelochemicals can also alter membrane permeability to mineral ions. In the presence of salicylic acid, efflux of phosphate from barley root (Glass, 1973) and efflux of $\mathrm{K}^{+}$from oat root (Balke, 1985) were reported. Narwal et al., (2005) reported that several phenolic acids inhibited $\mathrm{P}$ and $\mathrm{K}$ uptake due to an increase in the membrane permeability to inorganic ions. It was found that uptake of phosphate by excised barley root was inhibited in the presence of $p$ hydroxy-benzoic acid (PHBA) immediately but when PHBA was removed then rate of uptake was restored to almost that of control within few minute (Glass, 1974). The immediate and dramatic effect of the allelochemicals strongly implied that they acted directly upon the cell membrane. 
Table.1 Effect of different concentrations of aqueous extract of Jatropha curcas on germination $(\%)$, germination index, plumule and radicle length, plumule and radicle fresh weights and plumule and radicle dry weight of chilli

\begin{tabular}{|c|c|c|c|c|c|c|c|c|}
\hline 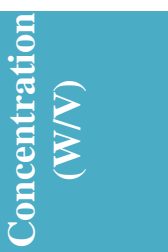 & 总 & 童 & 鄫 & 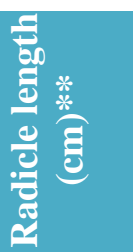 & 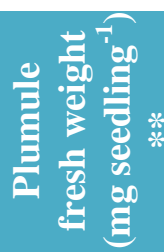 & 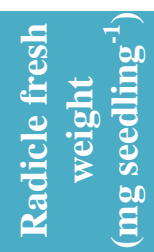 & 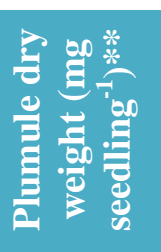 & 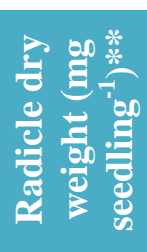 \\
\hline $5 \%$ & $\begin{array}{c}77.50 \\
(61.74)\end{array}$ & $\begin{array}{l}76.50 \\
(5.55)\end{array}$ & $\begin{array}{c}2.30 \\
(2.54)\end{array}$ & $\begin{array}{c}2.01 \\
(2.89)\end{array}$ & $\begin{array}{c}6.42 \\
(3.02)\end{array}$ & $\begin{array}{c}0.42 \\
(4.54)\end{array}$ & $\begin{array}{c}0.76 \\
(3.79)\end{array}$ & $\begin{array}{l}0.037 \\
(5.12)\end{array}$ \\
\hline $10 \%$ & $\begin{array}{c}67.50 \\
(55.26)\end{array}$ & $\begin{array}{c}70.00 \\
(13.58)\end{array}$ & $\begin{array}{c}2.25 \\
(4.66)\end{array}$ & $\begin{array}{c}1.93 \\
(6.76)\end{array}$ & $\begin{array}{c}6.27 \\
(5.28)\end{array}$ & $\begin{array}{c}0.41 \\
(6.81)\end{array}$ & $\begin{array}{c}0.72 \\
(8.86)\end{array}$ & $\begin{array}{c}0.035 \\
(10.25)\end{array}$ \\
\hline $15 \%$ & $\begin{array}{c}60.00 \\
(50.74)\end{array}$ & $\begin{array}{l}59.50 \\
(26.54)\end{array}$ & $\begin{array}{c}1.99 \\
(15.67)\end{array}$ & $\begin{array}{c}1.60 \\
(22.70)\end{array}$ & $\begin{array}{c}5.59 \\
(15.55)\end{array}$ & $\begin{array}{c}0.35 \\
(20.45)\end{array}$ & $\begin{array}{c}0.62 \\
(21.51)\end{array}$ & $\begin{array}{c}0.029 \\
(25.64)\end{array}$ \\
\hline $20 \%$ & $\begin{array}{c}50.00 \\
(44.98)\end{array}$ & $\begin{array}{c}48.50 \\
(40.12)\end{array}$ & $\begin{array}{c}1.72 \\
(27.11)\end{array}$ & $\begin{array}{c}1.29 \\
(37.63)\end{array}$ & $\begin{array}{c}4.47 \\
(32.47)\end{array}$ & $\begin{array}{c}0.29 \\
(34.09)\end{array}$ & $\begin{array}{c}0.52 \\
(34.17)\end{array}$ & $\begin{array}{c}0.024 \\
(38.46)\end{array}$ \\
\hline Control & $\begin{array}{c}82.50 \\
(65.44)\end{array}$ & 81.00 & 2.36 & 2.07 & 6.62 & 0.44 & 0.79 & 0.039 \\
\hline S.Ed( $( \pm)$ & 2.74 & 2.17 & 0.05 & 0.07 & 0.17 & 0.01 & 0.02 & 0.001 \\
\hline $\mathrm{CD}(5 \%)$ & 5.83 & 4.61 & 0.11 & 0.14 & 0.35 & 0.02 & 0.04 & 0.003 \\
\hline
\end{tabular}

* Transformed values are in parentheses

** Data in parenthesis represents \% inhibition over control

Table.2 Effect of different concentrations of aqueous extract of Jatropha curcas on germination (\%), germination index, plumule and radicle length, plumule and radicle fresh weight and plumule and radicle dry weight of green gram

\begin{tabular}{|c|c|c|c|c|c|c|c|c|}
\hline 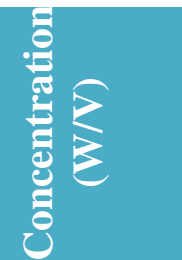 & 餖 & 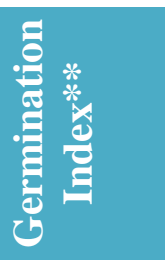 & 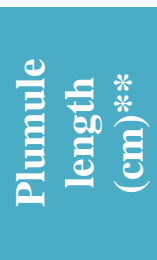 & 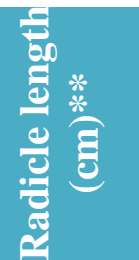 & 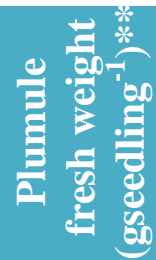 & 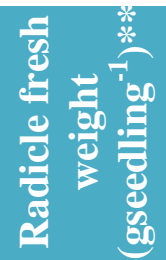 & 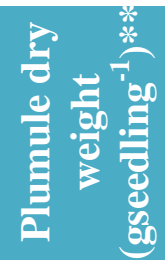 & 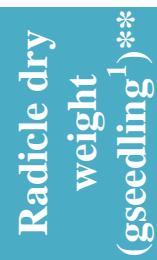 \\
\hline $5 \%$ & $\begin{array}{c}92.50 \\
(76.15)\end{array}$ & $\begin{array}{c}94.50 \\
(14.09)\end{array}$ & $\begin{array}{c}8.66 \\
(6.58)\end{array}$ & $\begin{array}{c}6.94 \\
(8.32)\end{array}$ & $\begin{array}{c}0.32 \\
(5.88)\end{array}$ & $\begin{array}{l}0.075 \\
(5.06)\end{array}$ & $\begin{array}{l}0.0182 \\
(3.70)\end{array}$ & $\begin{array}{c}0.0039 \\
(4.87)\end{array}$ \\
\hline $10 \%$ & $\begin{array}{c}82.50 \\
(65.44)\end{array}$ & $\begin{array}{c}87.50 \\
(20.45)\end{array}$ & $\begin{array}{c}6.36 \\
(31.39)\end{array}$ & $\begin{array}{c}4.69 \\
(38.04)\end{array}$ & $\begin{array}{c}0.25 \\
(26.47)\end{array}$ & $\begin{array}{c}0.055 \\
(30.37)\end{array}$ & & \\
\hline $15 \%$ & $\begin{array}{c}70.00 \\
(56.76)\end{array}$ & $\begin{array}{c}74.50 \\
(32.27)\end{array}$ & $\begin{array}{c}5.48 \\
(40.88)\end{array}$ & $\begin{array}{c}3.76 \\
(50.33)\end{array}$ & $\begin{array}{c}0.20 \\
(41.17)\end{array}$ & $\begin{array}{c}0.042 \\
(46.83)\end{array}$ & & $\begin{array}{l}0.0028 \\
(31.70)\end{array}$ \\
\hline $20 \%$ & $\begin{array}{c}47.50 \\
(43.54)\end{array}$ & $\begin{array}{c}62.50 \\
(43.18)\end{array}$ & $\begin{array}{c}3.68 \\
(60.30)\end{array}$ & $\begin{array}{c}2.62 \\
(65.38)\end{array}$ & $\begin{array}{c}0.15 \\
(55.88)\end{array}$ & $\begin{array}{c}0.034 \\
(56.96)\end{array}$ & $\begin{array}{l}0.0105 \\
(44.44)\end{array}$ & $\begin{array}{l}0.0022 \\
(46.34)\end{array}$ \\
\hline Control & $\begin{array}{c}97.50 \\
(85.38)\end{array}$ & 110.00 & 9.27 & 7.57 & 0.34 & 0.079 & 0.0189 & 0.0041 \\
\hline $\operatorname{S.Ed}( \pm)$ & 3.16 & 2.56 & 0.35 & 0.30 & 0.01 & 0.003 & 0.0009 & 0.0002 \\
\hline CD (5\%) & 6.73 & 5.45 & 0.74 & 0.64 & 0.02 & 0.006 & 0.0019 & 0.0004 \\
\hline
\end{tabular}

** Data in parenthesis represents \% inhibition over control *Transformed values are in parentheses 
Table.3 Effect of different concentrations of aqueous extract of Jatropha curcas leaf on leaf nitrogen, phosphorus and potassium of chilli

\begin{tabular}{|c|c|c|c|c|c|c|}
\hline \multirow[t]{2}{*}{$\begin{array}{c}\text { Concentration } \\
\text { (W/V) }\end{array}$} & \multicolumn{2}{|c|}{$\begin{array}{c}\text { Leaf nitrogen } \\
\text { content } \\
(\%, W / W)^{*}\end{array}$} & \multicolumn{2}{|c|}{$\begin{array}{c}\text { Leaf phosphorus } \\
\text { content } \\
(\%, W / W)^{*}\end{array}$} & \multicolumn{2}{|c|}{$\begin{array}{c}\text { Leaf potassium } \\
\text { content } \\
(\%, \mathrm{~W} / \mathrm{W})^{*}\end{array}$} \\
\hline & 50DAS & 110DAS & 50DAS & 110DAS & 50DAS & 110DAS \\
\hline $5 \%$ & $\begin{array}{c}2.92 \\
(5.80)\end{array}$ & 1.89 & $\begin{array}{l}0.203 \\
(6.88)\end{array}$ & 0.220 & $\begin{array}{c}3.92 \\
(6.66)\end{array}$ & 1.74 \\
\hline $10 \%$ & $\begin{array}{c}2.49 \\
(19.67)\end{array}$ & 1.84 & $\begin{array}{c}0.183 \\
(16.05)\end{array}$ & 0.218 & $\begin{array}{c}3.53 \\
(15.95)\end{array}$ & 1.70 \\
\hline $15 \%$ & $\begin{array}{c}2.24 \\
(27.74)\end{array}$ & 1.83 & $\begin{array}{c}0.155 \\
(28.89)\end{array}$ & 0.213 & $\begin{array}{c}3.30 \\
(21.42)\end{array}$ & 1.66 \\
\hline $20 \%$ & $\begin{array}{c}1.88 \\
(39.35)\end{array}$ & 1.75 & $\begin{array}{c}0.140 \\
(35.77)\end{array}$ & 0.210 & $\begin{array}{c}3.17 \\
(24.52)\end{array}$ & 1.54 \\
\hline Control & 3.10 & 1.94 & 0.218 & 0.223 & 4.20 & 1.78 \\
\hline S.Ed( $( \pm)$ & 0.08 & 0.06 & 0.006 & 0.008 & 0.07 & 0.15 \\
\hline CD (5\%) & 0.17 & NS & 0.013 & NS & 0.14 & NS \\
\hline
\end{tabular}

* Data in parenthesis represents \% inhibition over control

Table.4 Effect of different concentrations of aqueous extract of Jatropha curcas leaf on leaf nitrogen, phosphorus and potassium content of green gram

\begin{tabular}{|c|c|c|c|c|c|c|}
\hline \multirow[t]{2}{*}{$\begin{array}{l}\text { Concentration } \\
\text { (W/V) }\end{array}$} & \multicolumn{2}{|c|}{$\begin{array}{l}\text { Leaf nitrogen } \\
\text { content } \\
(\%, W / W)^{*}\end{array}$} & \multicolumn{2}{|c|}{$\begin{array}{c}\text { Leaf phosphorus } \\
\text { content } \\
(\%, W / W)^{*}\end{array}$} & \multicolumn{2}{|c|}{$\begin{array}{c}\text { Leaf potassium } \\
\text { content } \\
(\%, W / W)^{*}\end{array}$} \\
\hline & 30 DAS & 50 DAS & 30 DAS & 50 DAS & 30 DAS & 50 DAS \\
\hline $5 \%$ & $\begin{array}{l}2.09 \\
(7.47)\end{array}$ & $\begin{array}{c}1.83 \\
(5.67)\end{array}$ & $\begin{array}{c}0.155 \\
(18.42)\end{array}$ & $\begin{array}{c}0.121 \\
(36.31)\end{array}$ & $\begin{array}{c}1.87 \\
(6.03)\end{array}$ & $\begin{array}{c}1.62 \\
(7.95)\end{array}$ \\
\hline $10 \%$ & $\begin{array}{c}1.76 \\
(22.12)\end{array}$ & $\begin{array}{c}1.56 \\
(19.58)\end{array}$ & $\begin{array}{c}0.103 \\
(31.57)\end{array}$ & $\begin{array}{c}0.091 \\
(43.47)\end{array}$ & $\begin{array}{c}1.64 \\
(17.58)\end{array}$ & $\begin{array}{c}1.46 \\
(17.61)\end{array}$ \\
\hline $15 \%$ & $\begin{array}{c}1.47 \\
(34.95)\end{array}$ & $\begin{array}{c}1.24 \\
(36.08)\end{array}$ & $\begin{array}{c}0.082 \\
(56.84)\end{array}$ & $\begin{array}{c}0.070 \\
(56.52)\end{array}$ & $\begin{array}{c}1.28 \\
(35.67)\end{array}$ & $\begin{array}{c}1.11 \\
(36.93)\end{array}$ \\
\hline $20 \%$ & $\begin{array}{c}1.17 \\
(48.23)\end{array}$ & $\begin{array}{c}1.06 \\
(45.36)\end{array}$ & $\begin{array}{c}0.057 \\
(70.00)\end{array}$ & $\begin{array}{c}0.042 \\
(73.91)\end{array}$ & $\begin{array}{c}1.08 \\
(45.72)\end{array}$ & $\begin{array}{c}0.87 \\
(50.65)\end{array}$ \\
\hline Control & 2.25 & 1.94 & 0.190 & 0.161 & 1.99 & 1.76 \\
\hline S.Ed( \pm$)$ & 0.09 & 0.07 & 0.009 & 0.006 & 0.07 & 0.05 \\
\hline CD (5\%) & 0.19 & 0.14 & 0.020 & 0.013 & 0.14 & 0.11 \\
\hline
\end{tabular}

*Data in parenthesis represents \% inhibition over control 
Table.5 Effect of different concentrations of aqueous extract of Jatropha curcas leaf on total leaf chlorophyll content and relative leaf water content of chilli

\begin{tabular}{|c|c|c|c|c|}
\hline \multirow[t]{2}{*}{$\begin{array}{l}\text { Concentration } \\
\text { (W/V) }\end{array}$} & \multicolumn{2}{|c|}{$\begin{array}{l}\text { Total leaf chlorophyll content } \\
\quad\left(\mathrm{mg} \mathrm{g}^{-1} \text { fresh weight }\right)^{*}\end{array}$} & \multicolumn{2}{|c|}{ Relative leaf water content $(\%)$} \\
\hline & 50 DAS & 110 DAS & 50 DAS & 110 DAS \\
\hline $5 \%$ & $\begin{array}{c}1.67 \\
(9.72)\end{array}$ & 2.71 & $\begin{array}{c}66.43 \\
(10.07)\end{array}$ & 51.09 \\
\hline $10 \%$ & $\begin{array}{c}1.42 \\
(23.24)\end{array}$ & 2.63 & $\begin{array}{c}63.28 \\
(14.33)\end{array}$ & 50.86 \\
\hline $15 \%$ & $\begin{array}{c}1.24 \\
(32.97)\end{array}$ & 2.56 & $\begin{array}{c}56.62 \\
(23.35)\end{array}$ & 50.62 \\
\hline $20 \%$ & $\begin{array}{c}1.12 \\
(39.45)\end{array}$ & 2.52 & $\begin{array}{c}51.07 \\
(30.86)\end{array}$ & 50.54 \\
\hline Control & 1.85 & 2.76 & 73.87 & 51.33 \\
\hline S.Ed( $( \pm)$ & 0.05 & 0.12 & 1.39 & 0.43 \\
\hline $\mathrm{CD}(5 \%)$ & 0.11 & NS & 2.95 & NS \\
\hline
\end{tabular}

* Data in parenthesis represents \% inhibition over control

Table.6 Effect of different concentrations of aqueous extract of Jatropha curcas leaf on total leaf chlorophyll content and relative leaf water content of green gram

\begin{tabular}{|c|c|c|c|c|}
\hline \multirow[t]{2}{*}{$\begin{array}{l}\text { Concentration } \\
\text { (W/V) }\end{array}$} & \multicolumn{2}{|c|}{$\begin{array}{l}\text { Total leaf chlorophyll content } \\
\text { ( } \mathrm{mg} \mathrm{g}^{-1} \text { fresh weight)* }\end{array}$} & \multicolumn{2}{|c|}{ Relative leaf water content $(\%)$} \\
\hline & 30 DAS & 50 DAS & 30 DAS & 50 DAS \\
\hline $5 \%$ & $\begin{array}{c}1.54 \\
(15.84)\end{array}$ & $\begin{array}{c}2.32 \\
(6.45)\end{array}$ & $\begin{array}{l}68.15 \\
(3.74)\end{array}$ & $\begin{array}{l}52.97 \\
(6.66)\end{array}$ \\
\hline $10 \%$ & $\begin{array}{c}1.40 \\
(23.49)\end{array}$ & $\begin{array}{c}2.08 \\
(16.12)\end{array}$ & $\begin{array}{c}62.20 \\
(12.14)\end{array}$ & $\begin{array}{c}45.77 \\
(15.82)\end{array}$ \\
\hline $15 \%$ & $\begin{array}{c}1.27 \\
(30.60)\end{array}$ & $\begin{array}{c}1.73 \\
(30.24)\end{array}$ & $\begin{array}{c}56.82 \\
(19.74)\end{array}$ & $\begin{array}{c}41.72 \\
(26.48)\end{array}$ \\
\hline $20 \%$ & $\begin{array}{c}1.03 \\
(43.71)\end{array}$ & $\begin{array}{c}1.49 \\
(39.91)\end{array}$ & $\begin{array}{c}42.67 \\
(39.73)\end{array}$ & $\begin{array}{c}39.57 \\
(30.27)\end{array}$ \\
\hline Control & 1.83 & 2.48 & 70.80 & 56.75 \\
\hline S.Ed( \pm$)$ & 0.06 & 0.08 & 1.46 & 0.77 \\
\hline CD (5\%) & 0.11 & 0.17 & 3.11 & 1.63 \\
\hline
\end{tabular}

*Data in parenthesis represents \% inhibition over control 
Fig.1 Effect of 20\% (W/V) concentration of aqueous extract of Jatropha curcas leaf on percent inhibition of germination percentage, plumule and radicle length and fresh and dry weights of plumule and radicle of chilli and green gram

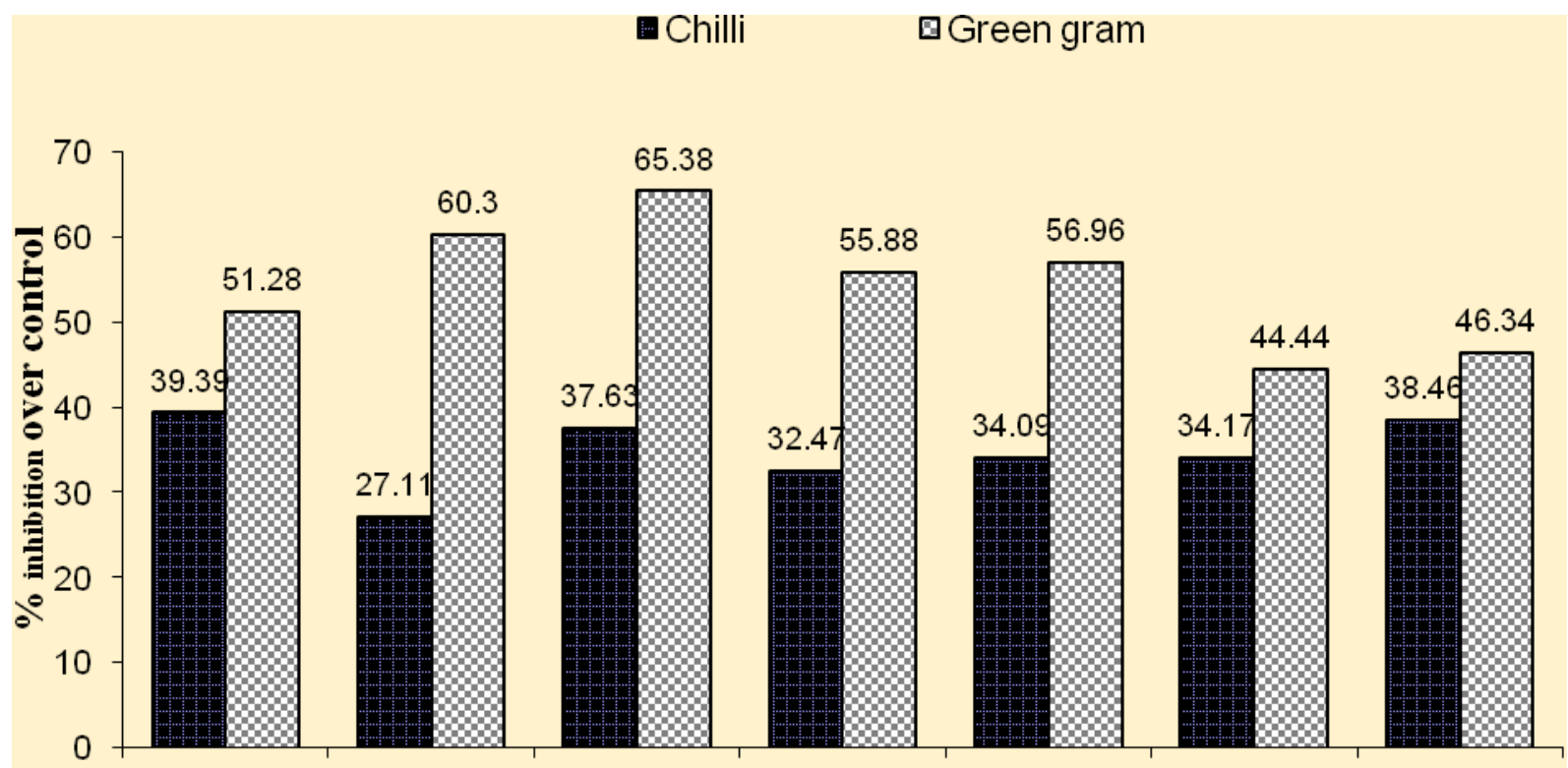

Germination perceflagiale lengttRadicle lengtilumule fresh Radicle fresh wRlumule dry wRadicle dry wt

Fig.2 Effect of different concentrations of aqueous extract of Jatropha curcas leaf on shoot dry weight of chilli. Data presented are means \pm S.Ed (Vertical bars)

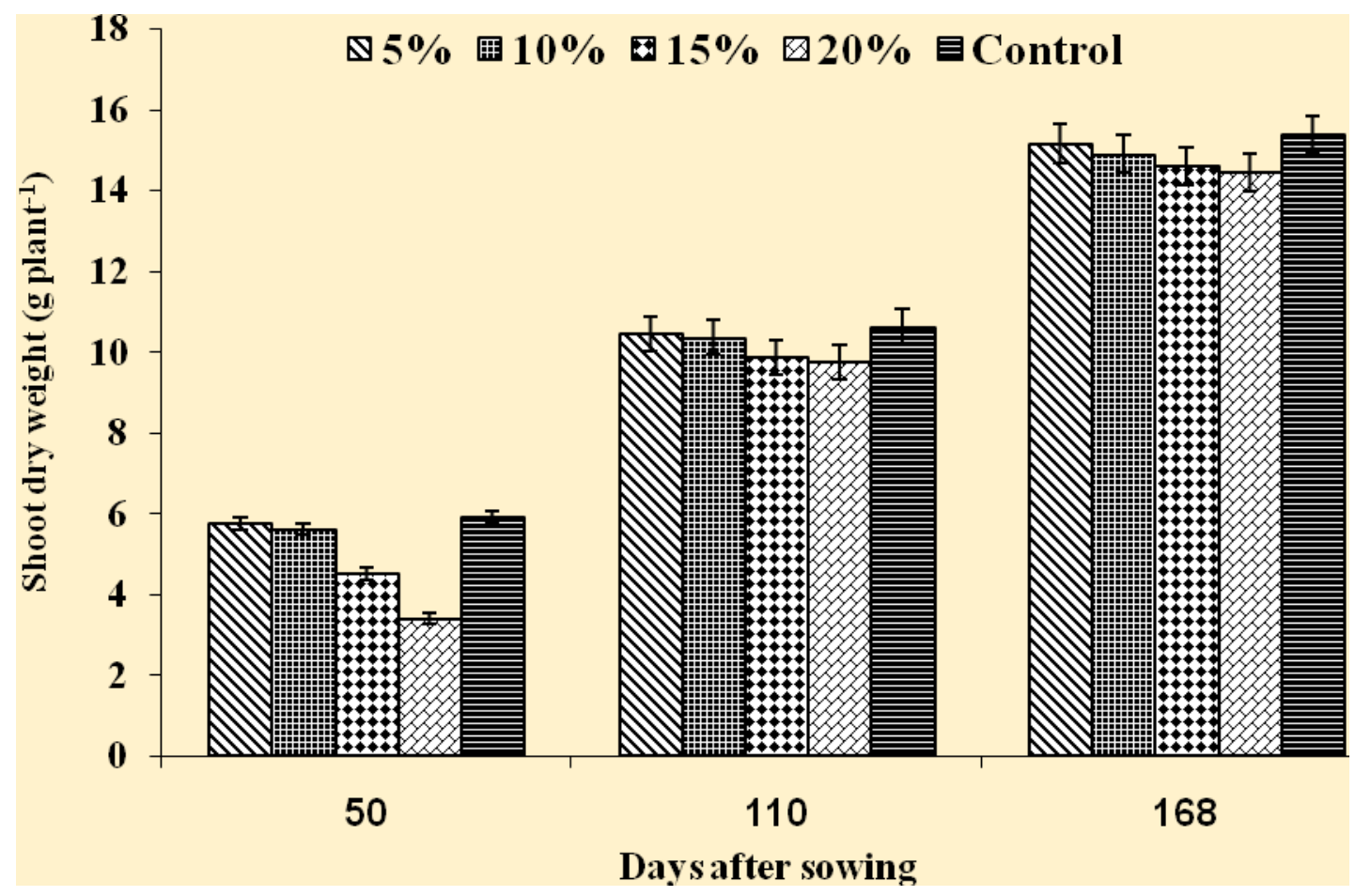


Fig.3 Effect of different concentrations of aqueous extract of Jatropha curcas leaf on root dry weight of chilli. Data presented are means \pm S.Ed (Vertical bars)

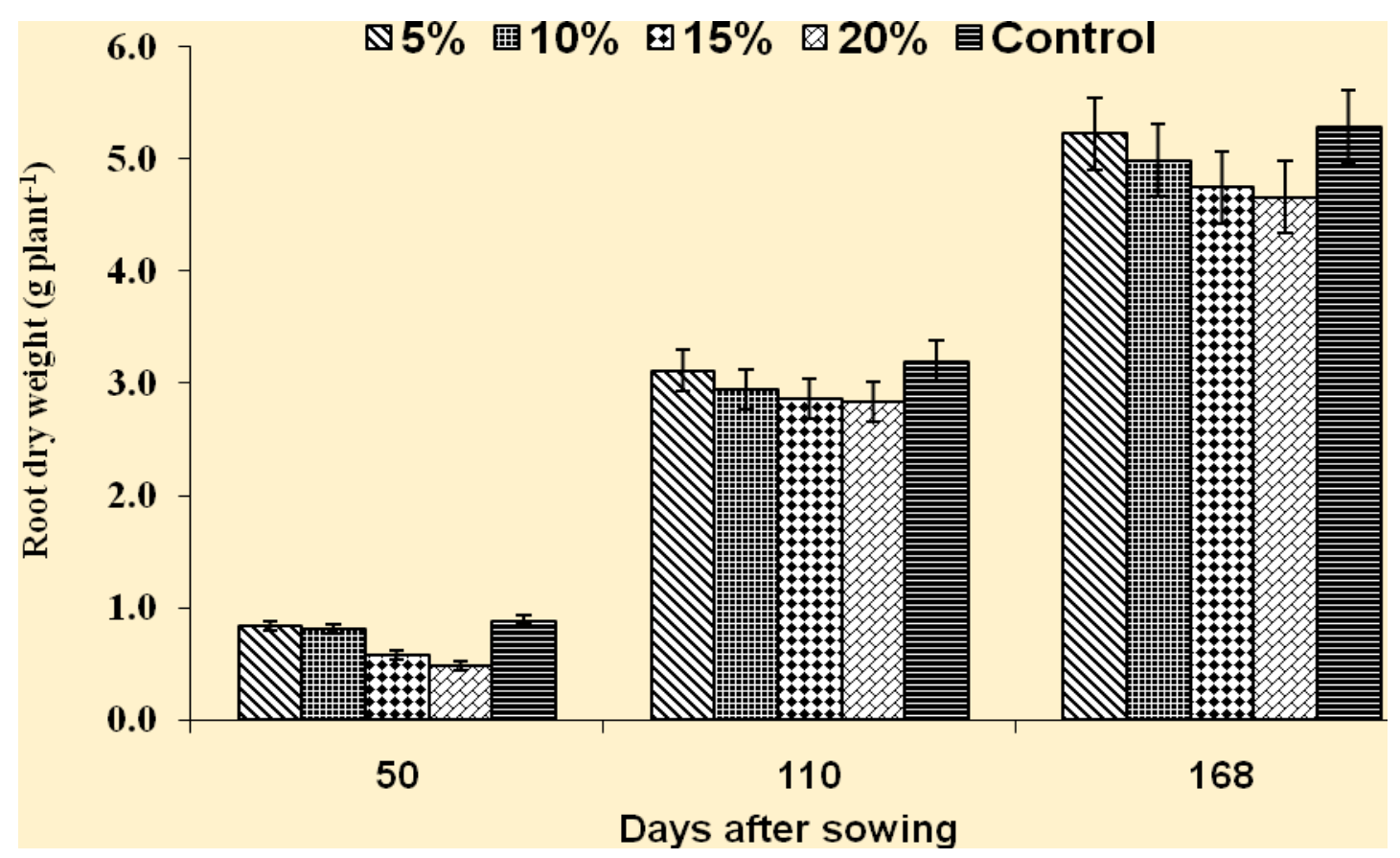

Fig.4 Effect of different concentrations of aqueous extract of Jatropha curcas leaf on shoot dry weight of green gram. Data presented are means \pm S.Ed (Vertical bars)

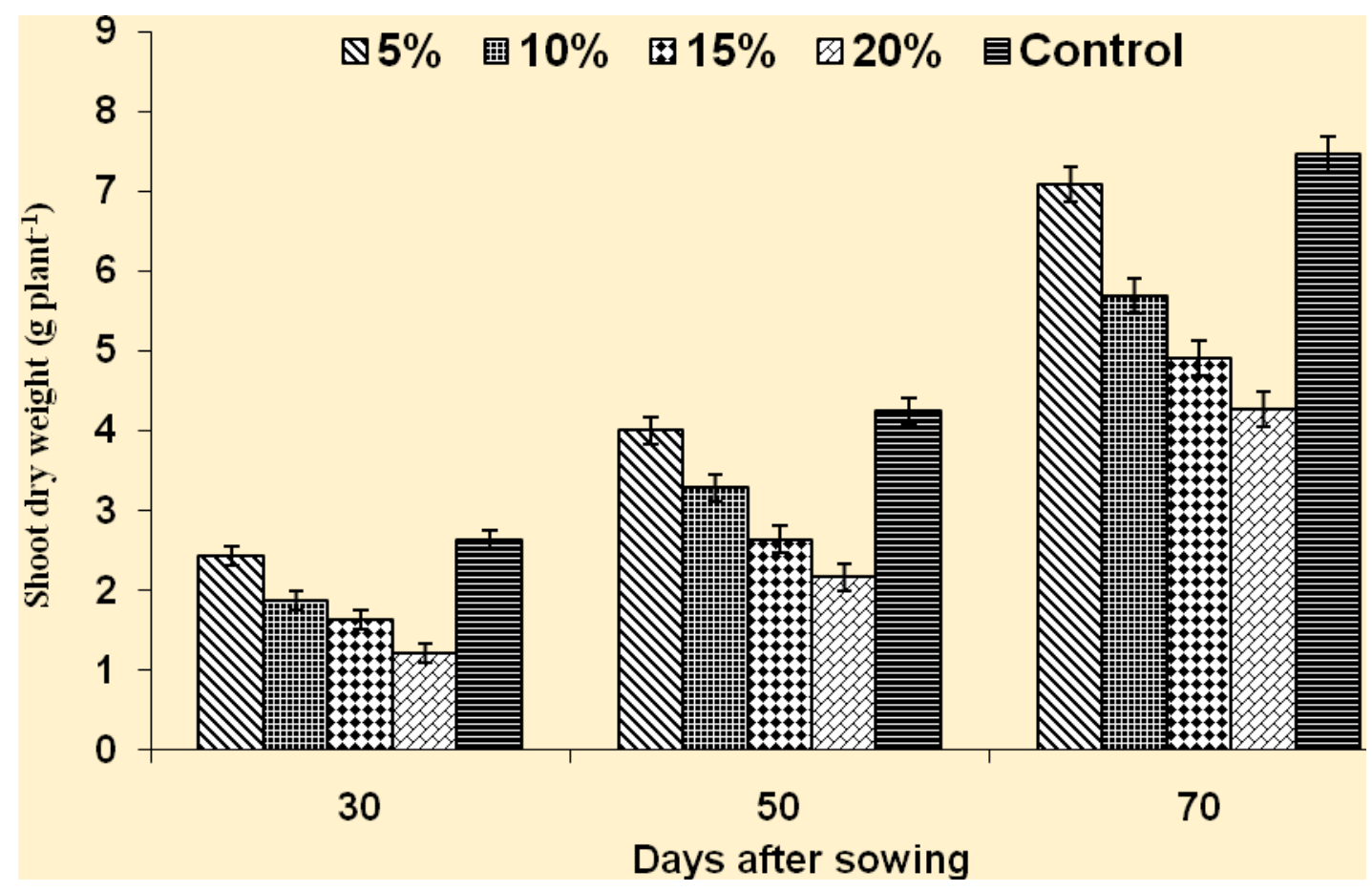


Fig.5 Effect of different concentrations of aqueous extract of Jatropha curcas leaf on root dry weight of green gram. Data presented are means \pm S.Ed (Vertical bars)

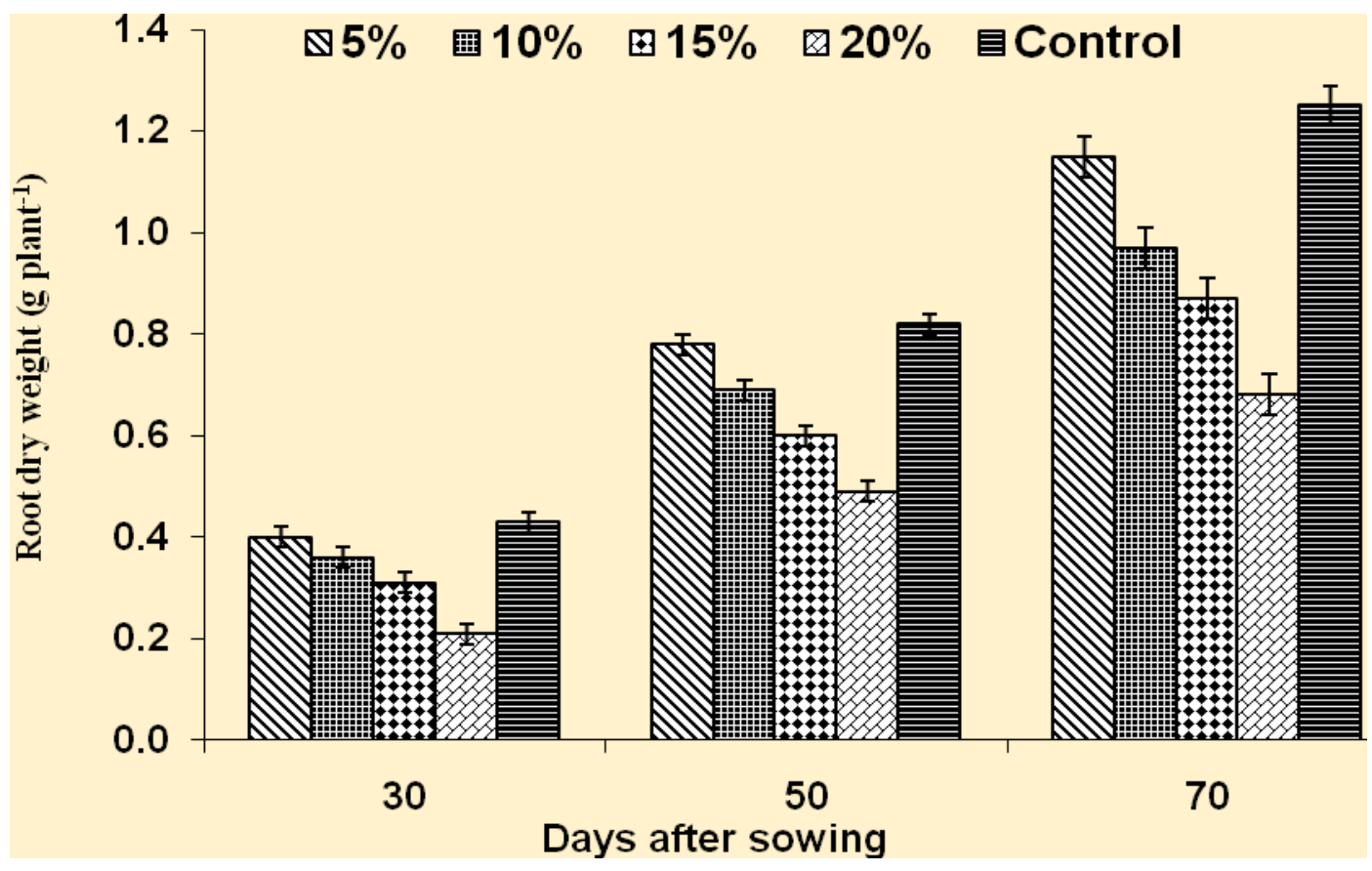

Fig.6 Effect of different concentrations of aqueous extract of Jatropha curcas leaf on leaf proline content of chilli. Data presented are means \pm S.Ed (Vertical bars)

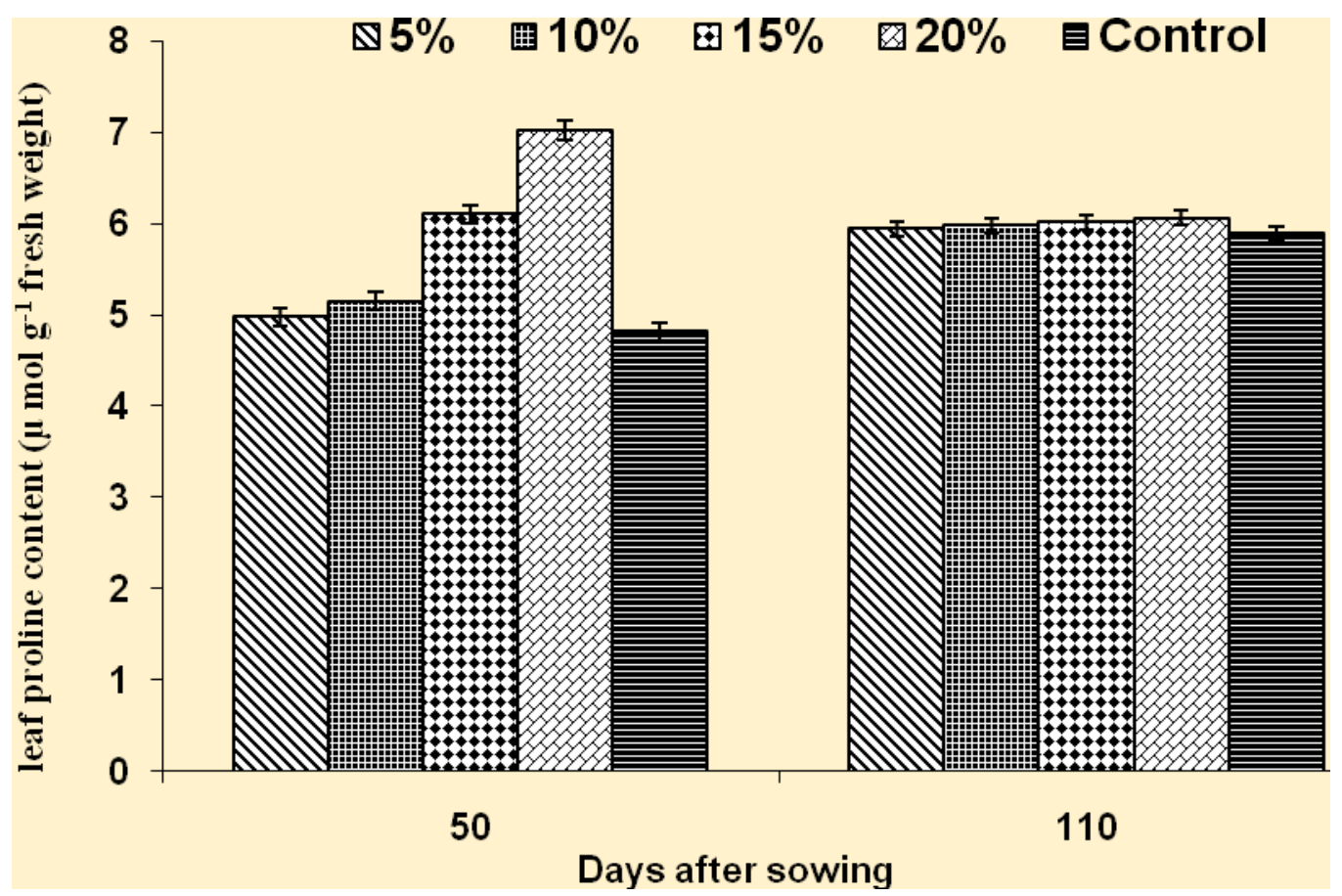


Fig.7 Effect of different concentrations of aqueous extract of Jatropha curcas leaf on leaf proline content of green gram. Data presented are means \pm S.Ed (Vertical bars)

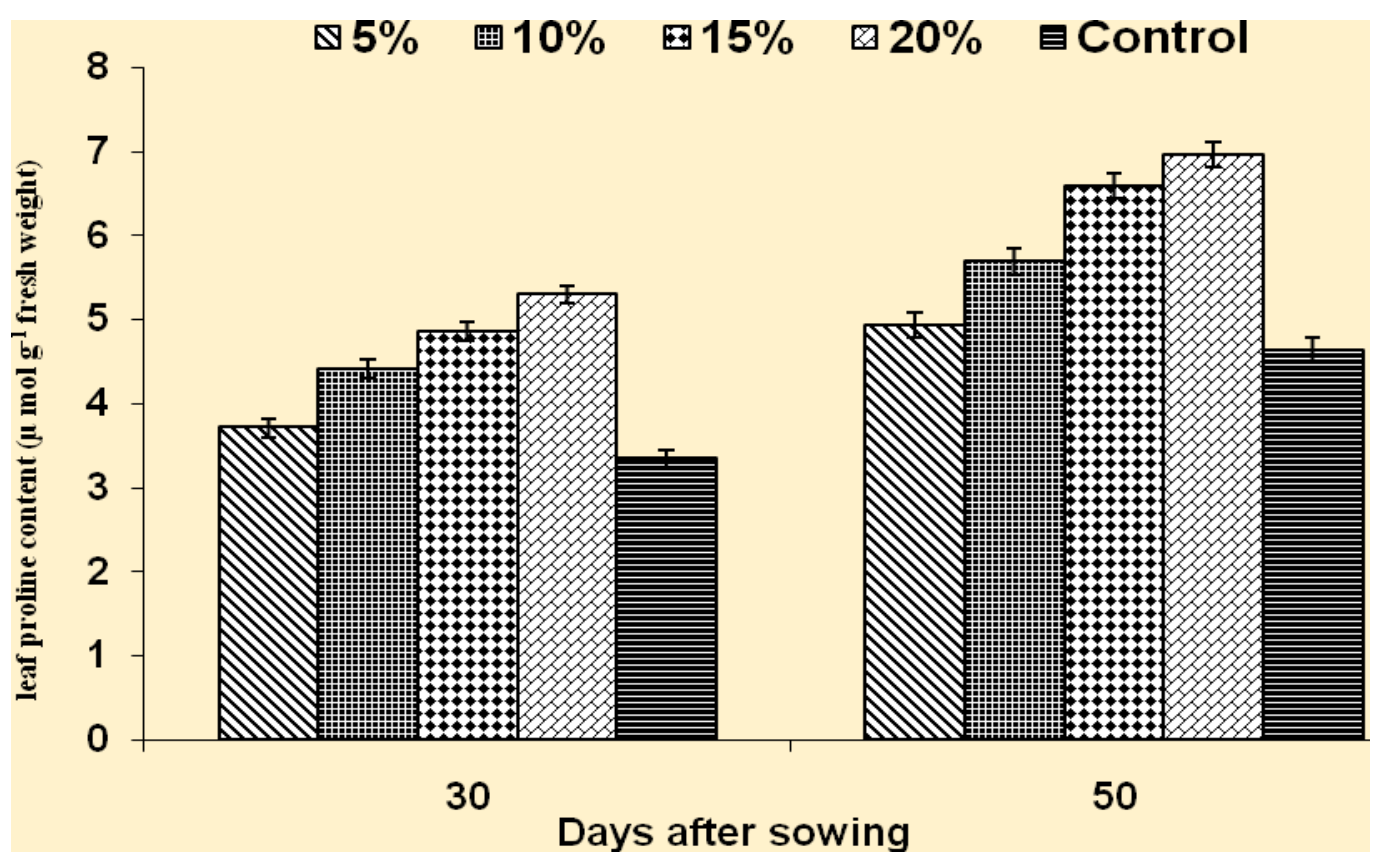

Fig.8 Effect of 20\% (W/V) concentration of aqueous extract of Jatropha curcas leaf on percent inhibition of leaf area, shoot and dry weight, total chlorophyll content and relative leaf water content of chilli and green gram at vegetative stage

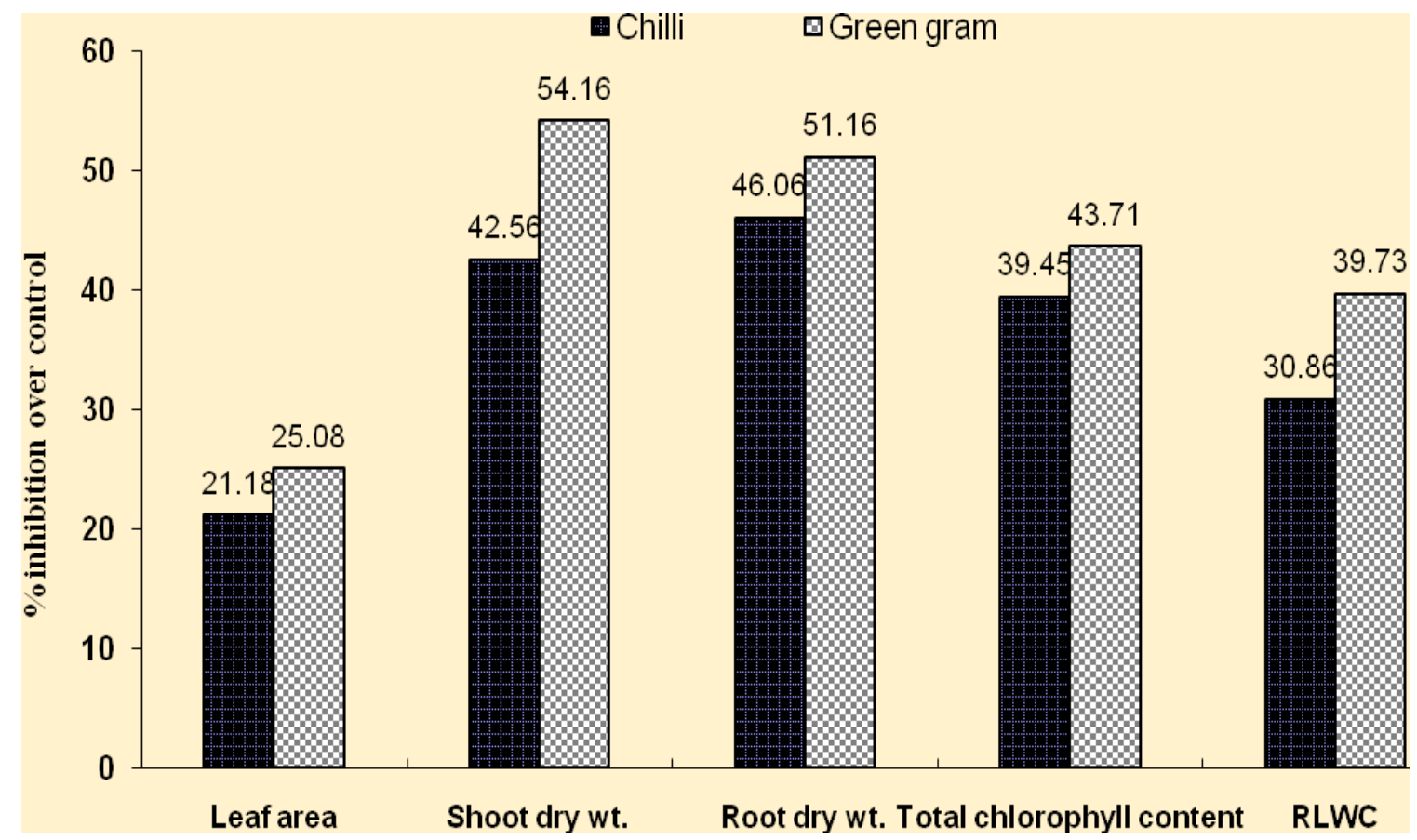


Immediate onset of recovery of mineral uptake on removal of allelochemicals indicated that the inhibitor acted on membrane only. If it was acting on cytoplasmic processes, it is reasonable to suppose that there would be some delay while the inhibitor was washed out or removed by detoxification. Glass (1973) and Glass and Dunlop (1974) suggested that the allelochemicals were solubilized into cellular membrane and thus caused 'loosening' of the membrane structure so that minerals can leak out across the membrane. Weir et al., (2004) reported that allelochemicals, such as ferulic acid could induce lipid peroxidation, and disrupt certain enzymatic activity and thereby led to loss in membrane permeability and eventual blocked nutrient uptake. Similarly, Keller et al., (2008) reported that hydroquinone, a potent allelochemical, disrupted membrane transport of root cell.

Therefore, it is reasonable to suggest that physiological mechanisms of actions of allelochemicals upon mineral uptake involve depolarization of electrical potential difference across the membrane, decreased ATP content in cell, alteration of ATPase activity and permeability of membrane to mineral ions. But it is possible that allelochemicals may produce more than one effect on the cellular processes responsible for mineral absorption.

Allelochemicals can reduce the chlorophyll and porphyrin content and in turn affecting photosynthesis and the total plant growth (Siddiqui and Zaman, 2005).The photosynthesis potential in plants is directly proportional with the chlorophyll content present in leaf tissues which play an important role in photochemical reactions (Schlemmer et al., 2005). Any changes in chlorophyll content are expected to bring about change in photosynthesis (Reigosa et al., 2006). In the present investigation, total chlorophyll content of green gram leaves was found to be reduced by all applied concentrations of aqueous extract of jatropha leaf (Table 5). This inhibitory effect was observed both at early and later stages of growth. However, in case of chilli, aqueous extract failed to produce such inhibitory effect, especially at the later stages (reproductive stage) of growth (Table 6). This finding is in line with the results reported by Oyerinde et al., (2009) they demonstrated that in various reviver plants chlorophyll a, chlorophyll b and total chlorophyll accumulations were reduced by allelochemicals released from donor plants. Various allelochemicals such as caffeic, tcinamic, p-coumaric, ferulic, gallic and vanillic acid were also reported to reduce chlorophyll content of soybean (Patterson, 1981). Rajangam et al., (1992) reported that chlorophyll content was less in several rice genotypes treated with leaf residues of Croton sparsiflorus. Similarly, Shora et al., (2015) reported, reduction in chlorophyll contents of Portulaca oleracea by leaf aqueous extract of Trichodesma africanum L. It has been reported that allelochemicals can reduce chlorophyll accumulation in plants by three ways: 1 . inhibition of synthesis, 2 . stimulation of degradation and 3. Both inhibition of synthesis and stimulation of degradation (Yang et al., 2002). Einhellig and Rasmussen (1979) suggested that reduction in chlorophyll content occurred only after some other physiological processes were altered by allelochemicals, but they could not conclude whether the reduction was because of degradation or reduction in synthesis of chlorophyll. However, Kanchan and Jayachandra (1980) suggested allelochemicalinduced chlorophyll reduction might be primarily due to enhanced degradation of chlorophyll; alternately, allelochemicals could reduced the synthesis of $\mathrm{Mg}$-porphyrin.

The importance of plant water status has widely been recognized for the maintenance 
of cellular turgidity, which is required for normal growth and survival of plant. From this present investigation, it is evident that relative leaf water contents (RLWC) of two tested crops were altered by aqueous extract of jatropha leaf (Table 5 and 6). At 50 DAS (vegetative stage), RLWC of chilli was reduced by aqueous extract of jatropha. However, such inhibitory effect was not recorded in the latter stages of growth of the crop.

In contrast, in case of green gram, the applied concentrations of aqueous extract showed significant reduction in RLWC both at 30 DAS (vegetative stage) and 50 DAS. Drop in water potential and increase in leaf resistance in plants under allelopathic treatments may be the cause for observed decrease in relative leaf water content as suggested by Schon and Einhellig (1982). Additionally, it can also be suggested that decrease in tissue water content was possibly due to corking and clogging of xylem vessels because of accumulation of lignin and pectic compounds under the influence of allelochemicals as reported by Bogdon (1971).

Proline plays an important role in ameliorating environmental stresses. Proline protects proteins from denaturation by maintaining the hydration level (Wafa and Taisan, 2014). In the present investigation, the leaf proline content of chilli was found to be increased in the initial stages of growth, at later stages such increased in proline content was not observed (Fig. 6). Whereas, in case of green gram, aqueous extract of jatropha found to increased leaf proline content both at 30 DAS and 50 DAS (Fig. 7). This increase in proline content indicated that chemical stress was induced by aqueous extract of jatropha upon the tested crops. Pawar and Chavan (2004) reported similar type of result in sorghum. Abdulghadar and Nabat (2008) observed that with application of heliotrope leaves extracts, proline level is significantly increased in leaves of Dodder.

In the previous section, it has been mentioned that germination and seedling growth of chilli, compared to green gram, were appeared to be less sensitive to aqueous extract of jatropha leaf. Similar trend was recorded from the pot culture experiment also. Aqueous extract of jatropha leaf not noticeably reduced growth of chilli compared to green gram (Fig. 8).

Other workers (Callaway et al., 2005; Jensen and Ehlers, 2010) have also reported such type of variations in sensitivity among different crops to allelopathic interaction, as recorded in the present investigation. However, despite the ecological and agronomic importance of allelopathy, relatively little is known concerning the mechanism adopted by plants in defense against allelochemicals (Bais et al., 2006). Some workers hypothesized that reactive oxygen species (ROS) status is an important mechanism involved in the interspecific difference in response to allelochemicals.

Some plants have found ways to reduce the effects of allelochemicals produced by neighbouring plants. Detoxification mechanisms that are used by plants include the conjugation, sequestration or secretion of carbohydrates, and the oxidation of the phytotoxic compounds (Inderjit and Duke, 2003). Plants that are equipped to metabolize the benzoxazinone degradation product, benzoxazolin-1(3H)-one (BOA), detoxify this allelopathic compound through $\mathrm{N}$ glucosylation, through the addition of a pentose sugar moiety or by hydroxylation followed by glucosylation (Von et al., 2001). These activities result in several structurally similar but less toxic products, such as BOA6-O-glucoside. Detoxification products are then released into the environment, where they are presumably metabolized by soil 
microorganisms, in root exudates (Sicker et al., 2001). Another detoxification mechanism used by plants is the glutathione Stransferase-catalyzed glutathionation of toxins and their subsequent transport out of the cytoplasm. In Arabidopsis thaliana, a $\mathrm{Mg}^{2+}$. ATPase transporter is responsible for the removal of glutathione S-conjugates from the cytosol (Lu et al., 1997). The sequence of the gene that encodes this transporter suggests that it is an ATP binding cassette transporter that is proficient in the transport of glutathione S-conjugates of xenobiotics and endogenous substances. In some cases, rhizosphere soil and micro-organisms may be credited with decreasing the phytotoxicity of allelopathic compounds, particularly phenolic acids. Soil that was rich in individual phenolic acids was able to induce colonization by bacteria that utilize phenolic acid, and these bacteria reduced the inhibition of seedling growth normally attributed to phenolic acids (Blum et al., 2000). Finally, phenolic acids react with soil via sorption and oxidation, decreasing their phytotoxicity (Ohno, 2001).

From the results it can be advocated that monoculture practices of crop production should be replaced by polyculture technologies owing to the stress of nutrient demand, disease infestation and poor yield (Rejila and Vijayakumar, 2011). In this respect, jatropha is an attractive crop since it may contribute to the income of farmers by improved agronomic procedures. However, it was reported that in polyculture too, some crops give better yield, while others exhibit poor growth and yield responses. One of the probable reasons for such variations is the differential allelopathic responses exhibited by different crop species. Results obtained from the present investigation revealed that yield of chilli was not affected by aqueous extract of jatropha. On the other hand, in green gram, the inhibitory effects of jatropha on growth and development was highly significant. Based on this result, it can be suggested that chilli is more suitable for intercropping in jatropha plantation than that of green gram.

\section{Acknowledgements}

The authors duly acknowledge the Department of Crop Physiology and Department of Horticulture, Assam Agricultural University, Jorhat for providing the necessary facilities to carry out the research work.

\section{References}

Abdulghader, K. and Nabat, M.N. (2008). Chemical stress induced by Heliotrope (Heliotropium europaem L.) Allelochemicals and increased activity of antioxidant enzymes. Pakistan J. Biol. Sci., 11(6): 915-919.

Abenavoli, M.R., Lupini, A., Oliva, S. and Sorgona, A. (2010). Allelochemical effects on net nitrate uptake and plasma membrane $\mathrm{H}^{+}$-ATPase activity in maize seedlings. Biologica Plantarum, 54(1): 149-153.

Abugre, S. and Sam, S.J.Q. (2010). Evaluating the allelopathic effect of Jatropha curcas aqueous extract on germination, radicle and plumule length of crops. Intern. J. Agril. Biol., 12: 769772.

Abugre, S., Twum-Ampofo, K. and OtiBoateng, C. (2015).Compatibility of Jatropha curcas with maize (Zea mays L.) cv. Obatampa in a hedgerow intercropping system grown on ferric acrisols. Agril. Forest. Fisher, 4(3): 109-116.

Bais, H.P., Weir, T.L., Perry, L.G., Gilroy, S. and Vivanco, J.M. (2006). The role of root exudates in rhizosphere interactions with plants and other organisms. Ann. Rev. Plant Biol., 57: 233-266. 
Balke, N.E. (1985). Effects of allelochemicals on mineral uptake an associated physiological processes. In: The Chemistry of allelopathy. Thormpson, A.C. (ed.), pp. 161-178.

Bhowmic, P.C. and Doll, J.D. (1982). Corn and soybean response to allelopathic effects of weed and crop residues. Agron. J., 74: 601-606.

Bhowmic, P.C. and Doll, J.D. (1984). Allelopathic effects of annual weed residues on growth and nutrient uptake of corn and soybean. Agron. J., 76: 383388.

Blum, U., Staman, K.L., Flint, L.J. and Shafer, S.R. (2000). Induction and/or selection of phenolic acid-utilizing bulk soil and rhizosphere bacteria and their influence on phenolic acid phytotoxicity. J. Chem.Ecol., 26: 20592078.

Brittaine, R. and Lutaladio, N. (2010). Jatropha: a smallholder bioenergy crop. The potential for pro-poor development integrated crop management. 8 IFAD/FAO.

Callaway, R.M., Hierro, J.L. and Thorpe, A.S. (2005). Evolutionary trajectories in plant and soil microbial communities: Centaurea invasions and the geographic mosaic of coevolution. In: Exotic species invasions: insights into ecology, evolution and biogeography. Sax, D.F., Gaines, S.D. and Stachowicz, J.J. (eds.). Sinauer, Sunderland, pp. 341-363.

Chambers, E.E. and Holm, L.G. (1965). Phosphorus uptake as influenced by associated plants. Weeds, 13: 312-314.

CSIS (Centre for Strategic and International Studies) (2006). India's Energy Dilemma.

Einhellig, F.A. and Rasmussen, J.A. (1979). Effects of three phenolic acids on chlorophyll content and growth of soybean and grain sorghum seedlings. $J$. Chem. Ecol., 5: 815-824.
Glass, A.D.M. and Dunlop, J. (1974). Influence of phenolic acids on ion uptake. IV. Depolarization of membrane potentials. Plant Physiol., 54: 855-858.

Goswami, K., Saikia, J. and Choudhury, H.K. (2011). Economic benefits and costs of jatropha plantation in North-East India. Agril. Econ. Res. Rev., 24: 99-108.

Harper, J.R. and Balke, N.E. (1981). Characterization of the inhibition of $\mathrm{K}^{+}$ absorption in oat roots by salicylic acid. Plant Physiol., 68: 1349-1353.

Hassan, A., Mukhtar, F.B. and Mohammed, I.M. (2013). Allelopathic effect of Jatropha curcas (Lin.) leachate on germination and early seedling growth of five (5) agricultural crops in Kano, Nigeria. Bayero J. Pure Appl. Sci., 6(2): 53-56.

Jensen, C.G. and Ehlers, B.K. (2010). Genetic variation for sensitivity to a thyme monoterpene in associated plant species. Oecologia, 162: 1017-1025.

Kanchan, S.D. and Jayachandra (1980). Pollen allelopathy: a new phenomenon. New Phytol., 84: 739-746.

Keller, C.P., Barkosky, R.R., Seil, J.E., Mazurek, S.A. and Grundstad, M.L. (2008). The electrical response of Phaseolus vulgaris roots to abrupt exposure to hydroquinone. Plant Sign. Behav., 3(9): 633-640.

Khan, M.A., Hussain, I. and Khan, E.A. (2008). Allelopathic effects of eucalyptus (Eucalyptus camaldulensis L.) on germination and seedling growth of wheat (Triticum aestivum L.). Pakistan J. Weed Sci. Res., 14(1-2): 918.

Koeppe, D.E. and Miller, R.J. (1974). Kaempferol inhibitions of corn mitochondrial phosphorylation. Plant Physiol., 54: 374-378.

Li, Z.H., Wang, Q., Ruan, X., Pan, C.D. and Jiang, D.A. (2010) Phenolics and plant allelopathy. Molecules, 15: 8933-8952. 
Lu, Y.P., Li, Z.S. and Rea, P. (1997). AtMRP1 gene of Arabidopsis encodes a glutathione S-conjugate pump: isolation and functional definition of a plant ATP-binding cassette transporter gene. Proc. National Academy of Sciences of the United States of America, 94: 82438248 .

Mathys, A. (2008). Assessment of the Current Biofuel Industry in India and Canada, Thesis, submitted to Queen's University, Ontario, Canada.

Narwal, S.S., Palaniraj, R. and Sati, S.C. (2005). Role of allelopathy in crop production. Herbologia, 6(2).

Norby, R.L. and Kozlowski, T.T. (1980). Allelopathic potential of ground cover species on Pinusresinosa seedlings. Plant and Soil, 57: 363-374.

Oyerinde, R.O., Otusanya, O.O. and Akpor, O.B. (2009). Allelopathic effect of Tithonia diversifolia on the germination, growth and chlorophyll contents of maize (Zea mays L.). Sci. Res. Essay 4(12): 1553-1558.

Patterson, D.T. (1981). Effects of allelopathic chemicals on growth and physiological response of soybean (Glycin max). Weed Sci. 29(1): 53-58.

Pawar, K.B. and Chavan, P.D. (2004). Influence of leaf leachates of some plant species on free proline content in germinating seeds of Sorghum bicolor (L.) Moench. Allelopathy J., 3: 89-92.

Rajangam, M., Selvaraj, M. and Natajan, R. (1992). Allopathic effects of Croton sparsiflorus on the germination and growth of paddy cultivars. Proc. First national Symp. (Allelopathy in Agro ecosystems) Hisar, India, pp.74-75.

Reigosa, M.J., Pedrol, N. and Gonzalez, L. (2006). Allelopathy: A Physiological Process with Ecological Chemists, 69: 98-101. Implications, 19: 299-330.

Rejila, S. and Vijayakumar, N. (2011). Allelopathic effect of Jatropha curcas on selected intercropping plants (Green Chilli and Sesame). J. Phytol., 3(5): 0103.

Rice, E.L. (1984). Allelopathy, $2^{\text {nd }}$ edition, Academic Press, Orlando, p. 422.

Saadaoui, E., José, J., Martín; Ghazel, N., Romdhane, C.B., Massoudi, N. and Cervantes, E. (2015). Allelopathic effects of aqueous extracts of Ricinus communis $\mathrm{L}$. on the germination of six cultivated species. Intern. J. Plant Soil Sci., 7(4): 220-227.

Schlemmer, M.R., Francis, D.D., Shanahan, J.F. and Schepers, J.S. (2005). Remotely measuring chlorophyll content in corn leaves with differing nitrogen levels and relative water content. Agron. J, 97(1): 106-112.

Schon, M.K. and Einhellig, F.A. (1982). Allelopathic effects of cultivated sunflower on grain sorghum. Bot. Gaz., 143: 505-510.

Shora, H.M., Aal, A. and Ibrahim, F.F. (2015). Allelopathic potential of Trichodesma africanum L.: Effects on germination, growth, chemical constituents and enzymes of Portulaca oleracea L. Intern. J. Curr. Microbiol. Appl. Sci., 4(9): 941-951.

Sicker, D., Schneider, B., Hennig, L., Knop, M. and Schulz, M. (2001). Glycoside carbamates from benzoxazolin-2(3H)one detoxification in extracts and exudates of corn roots. Phytochem.58:819-825.

Siddiqui, S., Bhardwaj, S., Khan, S.S. and Meghvanshi, M.K. (2009). Allelopathic effect of different concentration of water extract of Prosopsis juliflora leaf on seed germination and radicle length of wheat (Triticum aestivum Var-Lok-1). American-Eurasian J. Sci. Res., 4(2): 81-84.

Singh, R.A., Kumar, M. and Haider, E. (2007). Synergistic cropping of summer groundnut with Jatropha curcas new 
two-tier cropping system for Uttar Pradesh. J. SAT Agril. Res., 5(1).

Spolaore, P., Joannis-Cassan, C., Duran, E. and Isambert, A. (2006). Commercial applications of micro algae. J. Biosci. Bioenergy, 101: 87-96.

Swaminathan, C., Vinayrai, R.S. and Suresh, K.K. (1989). Allelopathic activities of Acacia nilotica. J. Trop. Forest Sci., 2: 56-60.

Ullah, F., Bano, A. and Nosheen, A. (2014). Sustainable Measures for Biodiesel Production. Energy Source, Part-A. Recovery Utilization and Environmental Effects, 36: 2621-2628.
Von, R.U., Huttl, R., Lottspiech, F., Gierl, A. and Frey, M. (2001). Two glucosyl transferases are involved in detoxification of benzoxazinoids in maize. The Plant J., 28: 633-642.

Weir, T.L., Park, S.W. and Vivanco, J.M. (2004). Biochemical and physiological mechanism mediated by allelochemicals. Curr. Opin. Plant Biol., 7: 472-479.

Yang, C.M., Lee, C.N. and Zhou, C.H. (2002). Effects of three allelopathicphenolics on chlorophyll accumulation of rice (Oryza sativa) seedlings. Bot. Bull. Acad. Sinica, 43: 299-304

\section{How to cite this article:}

Ujjal Baruah, Kaushik Das, Utpal Kotoky and Sonbeer Chack. 2018. Allelopathic Effect of Jatropha (Jatropha curcas) on Chilli (Capsicum annum) and Green Gram (Vigna radiata). Int.J.Curr.Microbiol.App.Sci. 7(06): 968-985. doi: https://doi.org/10.20546/ijcmas.2018.706.115 